\title{
HUBUNGAN ANTARA PENGETAHUAN TENTANG KEHAMILAN RESIKO TINGGI DAN TINGKAT DEPRESI PADA IBU HAMIL
}

\author{
Juwitasari $^{1}$, Marni $^{2}$ \\ 1, Departemen Keperawatan Maternitas, Fakultas Ilmu Kesehatan Universitas Muhammadiyah Malang \\ 2, Program Studi Ilmu Keperawatan Universitas Muhammadiyah Malang \\ *Email: juwita@umm.ac.id
}

\begin{abstract}
Abstrak
Kehamilan resiko tinggi berdampak pada fisik berupa pendarahan pada ibu dan gangguan pertumbuhan janin. Dampak psikologisnya dapat terjadi gangguan mood atau depresi saat kehamilan. Tujuan penelitian ini adalah untuk mengetahui hubungan antara tingkat pengetahuan tentang kehamilan resiko tinggi dengan tingkat depresi pada ibu hamil. Penelitian analitik observasional ini menggunakan desain cross sectional. Pemilihan sampel menggunakan teknik quota sampling, berjumlah 35 orang ibu hamil di wilayah RT.05 Kelurahan Karang Ambun, Kecamatan Tanjung Redeb, Kabupaten Berau dengan rentang usia 17-40 tahun, dalam periode kehamilan trimester 1 dan trimester 2 . Analisa data dilakukan dengan menggunakan Uji Korelasi Spearman. Hasil penelitian ini adalah mayoritas ibu hamil berusia > 35 tahun $(51,4 \%)$, dengan tingkat pendidikan SMA (60,0\%), yang bekerja sebagai IRT $(57,1 \%)$. Mayoritas ibu hamil memiliki jumlah anak hidup sebelum kehamilan sebanyak 2 orang sekitar $(28,6 \%)$. Mayoritas merupakan kehamilan ke 3 sebanyak $(28,6 \%)$, dan memiliki usia kandungan rata rata trimester II $(74,2 \%)$. Hasil uji Korelasi Spearman didapatkan $p$ value sebesar 0,003 $(<0,05)$ dengan koefisien korelasi sebesar $-0,488$ menunjukan ada korelasi negatif antara pengetahuan tentang kehamilan resiko tinggi dan tingkat depresi pada ibu hamil. Peningkatan pengetahuan ibu akan mempengaruhi sikap dan perilaku ibu selama masa kehamilan yang akan membuat ibu memiliki risiko depresi yang rendah.
\end{abstract}

Kata Kunci: Depresi, Ibu hamil, Kehamilan resiko tinggi, Pengetahuan

\begin{abstract}
The Relationship Between Knowledge Of High Risk Pregnancy And Depression In Pregnant Women. High-risk pregnancy has a physical impact in the form of bleeding in the mother and impaired fetal growth. The psychological impact can occur in mood disorders or depression during pregnancy. The purpose of this study was to determine the relationship between the level of knowledge about high-risk pregnancy and the level of depression in pregnant women. This observational analytic study used a cross sectional design. The sample selection used a quota sampling technique, totaling 35 pregnant women in the RT. 05 Kelurahan Karang Ambun, Tanjung Redeb District, Berau Regency with an age range of 17-40 years, in the 1st trimester and 2 nd trimester pregnancy periods. Data analysis was performed using the Test Spearman's Correlation. The results of this study were the majority of pregnant women aged $>35$ years (51.4\%), with a high school education level (60.0\%), who worked as IRT (57.1\%). The majority of pregnant women had 2 children alive before pregnancy (28.6\%). The majority were 3rd pregnancy (28.6\%), and had an average gestational age in the second trimester $(74.2 \%)$. The results of the Spearman Correlation test showed a p value of $0.003(<0.05)$ with a correlation coefficient of -0.488 indicating a negative correlation between knowledge of high-risk pregnancy and the level of depression in pregnant women. Increased knowledge of mothers will affect the attitudes and behavior of mothers during pregnancy which will make the mother have a low risk of depression.
\end{abstract}

Keywords: Depression, High Risk Pregnancy, Knowledge, Pregnant Women 


\section{Pendahuluan}

Kehamilan resiko tinggi adalah kehamilan yang berbahaya. Kehamilan risiko tinggi dapat menyebabkan terjadinya komplikasi yang lebih besar baik pada ibu maupun pada janin yang berada di dalam kandungan selama masa kehamilan, persalinan, ataupun nifas bila dibandingkan dengan kehamilan, persalinan dan nifas kehamilan yang normal (Fauzy, 2017). Kehamilan resiko tinggi terdiri dari 4T (4 Terlalu) yakni : terlalu tua usia ( $>35$ tahun), terlalu muda usia $(<19$ tahun), terlalu dekat jarak kehamilan (>3 kali dalam kurun waktu 2 tahun) dan terlalu banyak anak (Marcelya \& salafas, 2018). Beberapa penyebab terjadinya kehamilan resiko tinggi pada ibu hamil adalah kurangnya pengetahuan ibu tentang kesehatan reproduksi, rendahnya status sosial ekonomi dan pendidikan yang rendah (Meyliya Qudriani, 2017). Kehamilan resiko tinggi menjadi fenomena di masyarakat Indonesia, setidaknya ditemukan sekitar $65 \%$ ibu hamil memiliki resiko tinggi $4 \mathrm{~T}$ dalam kehamilannya (Budiman, 2017).

Menurut (kemenkes RI, 2016) 65\% penyebab kematian ibu hamil di Indonesia adalah akibat kehamilan resiko tinggi. Jumlah kasus kematian ibu hamil akibat kehamilan resiko tinggi di Negara ASEAN seperti Vietnam tercacat 160/100.000 jiwa per tahun, dan menurut WHO tercatat 305 kematian ibu per 100.000 kelahiran hidup di dunia disebabkan karena kehamilan resiko tinggi (Khadijah, 2018). Berdasarkan penelitian yang dilakukan di Puskesmas Papusungan Kec. Lembeh Selatan Kota Bitung

Sulawesi Utara pada tahun 2015 didapatkan hasil bahwa pengetahuan masyarakat tentang kehamilan resiko tinggi cukup rendah yakni 72\% (Corneles \& Losu, 2015). Berdasarkan hasil survey dan studi di Indonesia, hampir 50\% wanita hamil yang mengalami kehamilan resiko tinggi menderita gangguan psikologis, dan sekitar 23\%-50\% ibu hamil resiko tinggi mengalami gangguan depresi saat hamil (Fauzy, 2017).

Kehamilan resiko tinggi yang terjadi pada ibu hamil, tak hanya berdampak pada ibu hamilnya saja, tapi juga pada janin yang dikandungnya. Dampaknya bisa terjadi secara fisik maupun psikologis seperti : Preeklamsi, anemia, pendarahan, sampai pada kematian yang disertai dengan dampak psikologis berupa ketakutan, stres hingga terjadinya depresi dalam kehamilan yang tentu sangat membahayakan dan memperparah kondisi ibu (Fauzy, 2017). Sementara pada janin dampak yang terjadi IUFD (Intrauterine fetal Death), abortus dan BBLR (Berat Bayi Lahir Rendah (Marcelya, 2018). Tercatat $65 \%$ ibu hamil yang mengalami kehamilan resiko tinggi dan menderita depresi dalam kehamilannya berusia sekitar 20 s/d 35 tahun (Ratu 
Kusuma, 2019). Pada umumnya, depresi dalam kehamilan disebabkan karena beberapa faktor yakni : faktor usia, pendidikan, kehamilan, jumlah anak hidup serta kehamilan yang tidak diinginkan.

Depresi dalam kehamilan adalah gangguan mood dengan gejala berupa perasaan sedih, lebih sensitif sehingga mudah tersinggung bahkan sampai menangis, gelisah, tidak mempunyai harapan terhadap masa depan, gangguan tidur berupa mimpi buruk atau insomnia, penurunan nafsu makan, penurunan libido, gangguan interaksi sosial, mudah lelah sehingga mengalami gangguan dalam melakukan aktifitas sehari-hari, gangguan mengingat atau susah berkonsentrasi, bahkan beberapa ibu mengalami halusinasi sehingga beresiko mencederai diri sendiri dan orang lain disekitarnya (Ratu kusuma, 2019). Beberapa keluhan lain yang juga dirasakan ibu hamil yang mengalami depresi dalam kehamilan adalah keluhan yang berhubungan dengan asupan nutrisi seperti mual, muntah, kurang asupan makanan, penurunan nafsu makan, penurunan berat badan, kurus, pucat, pusing atau sakit kepala, dan penurunan tekanan darah. Tak hanya bagi ibu, depresi dalam kehamilan juga akan berdampak negatif pada janin yang dikandung. Dampak yang dapat terjadi yakni terganggunya tumbuh kembang janin, terjadinya aborsi dan BBLR (Berat Bayi Lahir Rendah) (Kusuma, 2019). Kejadian depresi saat kehamilan mencapai 23\% di dunia, 15-20\% di Asia, dan 25\% di Indonesia (Kusuma, 2019).

Berdasarkan pemaparan diatas, peneliti tertarik untuk mengetahui apakah ada hubungan antara tingkat pengetahuan tentang kehamilan resiko tinggi dan tingkat depresi pada ibu hamil

\section{Metode}

Jenis penelitian ini adalah korelasional dengan pendekatan Cross sectional. Teknik sampling yang digunakan dalam penelitian ini yaitu quota sampling. Sampel dalam penelitian ini sebanyak 35 orang ibu hamil usia 17 s/d 40 tahun di wilayah RT. V Kelurahan Karang Ambun Kecamatan Tanjung Redeb, Kabupaten Berau, Kalimantan dalam rentang kehamilan trimester 2 dan 3. Instrumen yang digunakan dalam penelitian ini adalah kuesioner dengan skala likert, baik pengukuran tentang pengetahuan kehamilan resiko tinggi maupun tingkat depresi pada ibu hamil. Uji yang digunakan dalam penelitian ini yaitu Uji Korelasi Spearman. 


\section{Hasil}

Tabel 1 Karakteristik Subjek Penelitian

\begin{tabular}{|c|c|c|c|}
\hline No & Karakteristik & $\mathbf{f}$ & $\%$ \\
\hline \multirow[t]{3}{*}{1} & Usia (thn) & & \\
\hline & $<35$ & 17 & 48,6 \\
\hline & $>35$ & 18 & 51,4 \\
\hline \multirow[t]{4}{*}{2} & Pendidikan & & \\
\hline & SMP & 3 & 8,8 \\
\hline & SMA & 27 & 79,4 \\
\hline & S-1 & 4 & 11,8 \\
\hline \multirow[t]{6}{*}{3} & Pekerjaan & & \\
\hline & IRT & 20 & 57,1 \\
\hline & Guru & 4 & 11,4 \\
\hline & Wirausaha & 9 & 25,7 \\
\hline & Karyawan & 1 & 2,9 \\
\hline & PNS & 1 & 2,9 \\
\hline \multirow[t]{6}{*}{4} & $\begin{array}{l}\text { Jumlah Anak } \\
\text { hidup }\end{array}$ & & \\
\hline & 0 & 10 & 28,6 \\
\hline & 1 & 5 & 14,3 \\
\hline & 2 & 10 & 28,6 \\
\hline & 3 & 7 & 20 \\
\hline & 4 & 3 & 8,6 \\
\hline \multirow[t]{6}{*}{5} & Kehamilan Ke & & \\
\hline & 1 & 9 & 25,7 \\
\hline & 2 & 6 & 17,1 \\
\hline & 3 & 10 & 28,6 \\
\hline & 4 & 7 & 20 \\
\hline & 5 & 3 & 8,6 \\
\hline \multirow[t]{4}{*}{6} & Usia & & \\
\hline & Kehamilan & & \\
\hline & Trimester 1 & 26 & 74,3 \\
\hline & Trimester 2 & 9 & 25,7 \\
\hline Total & & 35 & $100 \%$ \\
\hline
\end{tabular}

Hasil deskripsi karakteristik usia diperoleh 17 orang berusia <35 tahun dan 18 orang berusia >35 tahun. Deskripsi karakteristik pendidikan mayoritas (21 orang) menempuh pendidikan SMA. Sebagian besar (21 orang) adalah ibu rumah tangga. Sejumlah 10 orang belum memiliki anak, 5 orang memiliki 1 anak, 10 orang memiliki 2 anak, 7 orang memiliki 3 anak, 3 orang memiliki 4 anak.

Sebanyak 9 orang ibu mengalami kehamilan ke-1, 6 orang adalah kehamilan ke-2, dan sisanya adalah kehamilan ke-3 atau lebih. Deskripsi usia kehamilan diperoleh mayoritas (26 orang) memasuki usia kehamilan trimester II.

Tabel 2 Hasil Deskripsi Variabel Tingkat Pengetahuan tentang Kehamilan Resiko Tinggi

\begin{tabular}{lrccl}
\hline No. Kategori & Interval & f & \% \\
\hline 1 & Rendah & $10-30$ & 18 & 51,4 \\
2 & Tinggi & $31-50$ & 17 & 48,6 \\
\hline \multicolumn{2}{c}{ Total } & & 35 & 100 \\
\hline
\end{tabular}

Hasil deskripsi variabel pengetahuan tentang kehamilan resiko tinggi diperoleh 18 orang atau 51,4 persen memiliki pengetahuan rendah dan 17 orang atau 48,6 persen memiliki pengetahuan tinggi.

\section{Tabel 3 Hasil Deskripsi Variabel Tingkat Depresi pada Ibu Hamil}

\begin{tabular}{lllll}
\hline No. & Kategori & Interval & $\mathbf{f}$ & $\mathbf{\%}$ \\
\hline 1 & Ringan & $20-60$ & 25 & 71,4 \\
2 & Berat & $61-100$ & 10 & 28,6 \\
\hline \multicolumn{2}{c}{ Total } & & 35 & 100 \\
\hline
\end{tabular}

Hasil deskripsi variabel depresi dalam kehamilan diperoleh 25 orang atau 71,4 persen mengalami depresi ringan dan 10 orang atau 28,6 persen mengalami depresi berat.

Berdasarkan hasil uji korelasi 
Spearman antara variabel pengetahuan tentang kehamilan resiko tinggi dan variabel depresi dalam kehamilan diperoleh koefisien korelasi sebesar -0,488 dengan nilai signifikansi sebesar 0,003 . Hasil tersebut menunjukkan adanya korelasi negatif signifikan, artinya semakin tinggi pengetahuan yang dimiliki ibu hamil akan berpengaruh terhadap semakin rendah tingkat depresi kehamilannya. Koefisien korelasi sebesar -0,488 juga menunjukkan tingkat hubungan antara variabel pengetahuan tentang kehamilan resiko tinggi dan variabel depresi dalam kehamilan berada pada tingkat sedang. Kekuatan hubungan berada pada rentang 0,26 - 0,50 yang artinya cukup kuat dengan arah hubungan bernilai negatif tidak searah.

\section{Pembahasan}

\section{Tingkat Pengetahuan Ibu Hamil tentang Kehamilan Resiko Tinggi}

Berdasarkan hasil penelitian yang telah dilakukan oleh peneliti terhadap ibu hamil di wilayah RT.05 Kelurahan Karang Ambun, Kecamatan Tanjung Redeb Kabupaten Berau, didapatkan hasil bahwa 18 orang memiliki tingkat pengetahuan yang rendah sedangkan 17 orang memiliki tingkat pengetahuan yang tinggi. Responden yang memiliki pengetahuan rendah tidak seluruhnya memiliki tingkat depresi yang tinggi, begitu pula dengan responden yang memiliki tingkat pengetahuan tinggi, tidak seluruhnya memiliki tingkat depresi yang rendah. Pada setiap soal yang diberikan dalam kuesioner tingkat pengetahuan, masing masing responden memiliki jawaban yang berbeda beda sesuai dengan apa yang mereka ketahui.

Terkait dengan apa itu kehamilan resiko tinggi, mayoritas ibu hamil memiliki pengetahuan yang sama dan tepat, hanya sebagian kecil saja yang belum memahami terkait kehamilan resiko tinggi. Terkait dengan pengaruh usia yang terlalu muda atau terlalu tua saat mengandung, mayoritas ibu hamil memahami pengaruh usia pada kehamilan, sedangkan pada jarak kehamilan, hampir sebagian ibu hamil belum mengetahui bahwa jarak kehamilan juga memiliki pengaruh yang besar terhadap kejadian kehamilan resiko tinggi.

Menurut Notoatmodjo (2017) tingkat pengetahuan seseorang dapat dipengaruhi oleh usia dan tingkat pendidikan. pengetahuan merupakan hasil "tahu" dan ini terjadi setelah orang mengadakan penginderaan terhadap suatu objek tertentu. Penginderaan terhadap objek terjadi melalui panca indra manusia yakni penglihatan, pendengaran, penciuman, rasa dan raba dengan sendiri. Pada waktu penginderaan sampai menghasilkan pengetahuan tersebut sangat dipengaruhi oleh intensitas perhatian persepsi terhadap objek. Sebagian besar pengetahuan manusia diperoleh melalui 
mata dan telinga.

Astuti (2017) menyebutkan Kehamilan risiko tinggi merupakan kehamilan yang memungkinkan terjadinya komplikasi pada saat kehamilan dan persalinan dari risiko yang dimiliki ibu dibandingkan dengan kehamilan normal. Kehamilan mempunyai risiko tinggi jika dipengaruhi oleh faktor pemicu yang akan menyebabkan terjadinya komplikasi selama kehamilan, bahkan saat persalinan berlangsung dan juga saat masa nifas. Oleh karena itu, untuk mengetahui apakah ibu hamil memiliki risiko tinggi, maka dilakukan deteksi dini dengan melakukan anamnesis, pemeriksaan kehamilan dan pemeriksaan penunjang jika dibutuhkan.

Penelitian Parida Hanum (2018) yang telah dilakukan peneliti di Klinik Pratama Sunggal Medan Januari sampai Desember 2017 didapatkan ibu hamil umur $<19$ tahun 4 orang, usia $>35$ tahun 26 orang, paritas $>3$ kali 26 orang, dekat jarak melahirkan $<2$ tahun 25 orang. Hasil dari wawancara yang dilakukan oleh peneliti terhadap 9 orang ibu hamil yang datang ke klinik didapatkan 5 orang dari 9 orang ibu hamil kurang mengetahui tentang kejadian risiko tinggi kehamilan. "Hubungan Pengetahuan dan Sikap Ibu Hamil dengan Kejadian Risiko Tinggi Kehamilan” di Klinik Pratama Sunggal Medan.

\section{Gambaran Tingkat Depresi pada Ibu Hamil}

Setiap ibu hamil yang menjadi responden dalam penelitian ini memiliki perasaan yang berbeda beda, sesuai dengan kondisi yang saat itu sedang mereka rasakan selama proses kehamilannya. Sebagian besar ibu hamil tidak sedih jika memikirkan tentang kehamilannya, hanya ada sedikit saja yang saja sedih jika memikirkan tentang kehamilan. Terkait, perasaan mudah tersinggung, mayoritas ibu hamil tidak mudah tersinggung dan sangat sedikit yang mudah tersinggung jika di bahas tentang kehamilannya.

Beberapa ibu hamil yang mudah menangis tanpa sebab di masa masa kehamilannya, tetapi mayoritas tidak mudah menangis. Perasaan mudah lelah kadang sering dialami oleh ibu yang sedang hamil, dan pada ibu hamil yang berada di wilayah kelurahan karang ambun pun sama, hampir sebagian besar mudah lelah saat hamil. Sebagian besar ibu hamil mengalami kesulitan untuk tidur di malam hari dan malas melakukan aktivitas saat hamil. Kemudian, berkaitan dengan nafsu makan, mayoritas ibu hamil di kelurahan karang ambun tidak mengalami penurunan nafsu makan, dan sangat sedikit yang mengalami kehilangan nafsu makan. Berkaitan dengan gangguan halusinasi, hampir sebagian besar ibu hamil tidak ada yang mengalami gangguan halusinasi namun sepertiga dari ibu hamil lebih sensitif ketika hamil.

Hal yang dikhawatirkan ketika 
seorang ibu hamil mengalami depresi adalah upaya untuk mengakhiri hidup atau bunuh diri, namun ketika diteliti, hampir sebagian besar dari jumlah ibu hamil yang diteliti tidak pernah terfikir untuk melakukan upaya tersebut, dan hanya ada satu orang yang pernah terlintas untuk mengakhiri hidupnya. Dalam kuesioner yang diberikan pada ibu hamil melalui link google form tersebut, peneliti mencoba untuk menggali lebih dalam terkait perasaan ibu saat hamil saat itu, dan ketika dilihat pada soal kesebelas, berkaitan dengan rasa takut jika kehamilannya tidak disukai oleh orang sekitar, rata rata ibu hamil mengaku biasa saja dan tidak takut dengan kehamilan yang sekarang, namun, ada sekitar 7 orang ibu hamil mengaku takut jika kehamilannya tidak disukai oleh orang orang sekitar. Rasa takut terkait ketidakmampuan untuk membiayai bayi ketika lahir juga tidak dialami oleh ibu hamil, ada kemungkinan jika rata rata perekonomian ibu hamil yang ada dalam penelitian cukup baik. Ketika peneliti melakukan observasi terhadap usia Ibu hamil saat mengandung, perbandingan usia antara ibu hamil > 35 tahun dan ibu hamil <35 tahun hampir seimbang. Ketika ditanya tentang kekhawatiran dengan usia saat mengandung, sebagian besar ibu hamil mengaku biasa saja dan tidak takut dengan usianya saat mengandung. Berkaitan dengan rasa panic, sebagian besar ibu hamil tidak mengalami itu. Pada soal nomor 15, tentang perasaan bingung, sebagian besar dari ibu hamil tidak mengalaminya, dan hanya ada enam orang dari seluruh responden yang mengaku bingung apa yang harus dilakukan saat bayi lahir. Namun, mayoritas ibu hamil yang menjadi responden tidak mengalami rasa cemas yang berlebih saat kehamilannya, hanya sedikit saja yang cemas ketika memikirkan tentang kehamilannya. Hampir setengah dari ibu hamil mengaku mengalami peningkatan beban pikiran dan sedikit mual, namun hampir sebagian besar tidak mengalami penurunan berat badan namun ada 10 orang yang mengaku pusing dan sakit kepala saat hamil. Selebihnya biasa saja.

Fauzy (2016) menyebutkan bahwa depresi merupakan salah satu diantara bentuk gangguan keseimbangan mood (suasana perasaan). Mood adalah kondisi perasaan yang terus ada yang mewarnai kehidupan psikologis individu. Perasaan sedih atau depresi bukanlah hal yang abnormal dalam konteks peristiwa atau situasi yang penuh tekanan. Namun orang dengan gangguan mood yang luar biasa parah atau berlangsung lama akan mengganggu kemampuan mereka untuk berfungsi secara normal. Perasaan-perasaan khawatir, cemas dan sedih bisa terjadi pada individu dengan resiko tinggi. Menurut Azwar (2008), kehamilan dengan resiko tinggi adalah kehamilan yang memiliki 
risiko lebih besar dari biasanya (baik bagi ibu maupun bayinya), dapat menyebabkan terjadinya penyakit atau kecacatan bahkan kematian sebelum maupun sesudah persalinan.

$$
\text { Endang Fourianalisyawati, }
$$
menyebutkan (2016) bahwa gangguan depresi yang dialami saat hamil juga dapat berpengaruh pada kondisi kesehatan bayi. Pada penelitian yang dilakukan pada ibu yang memiliki gejala depresi, didapatkan berat badan bayi ketika lahir menjadi rendah. Gejala depresi lebih banyak terjadi pada kelompok ibu yang melahirkan Berat Bayi Lahir Rendah (BBLR) dibandingkan dengan ibu yang melahirkan bayi dengan Berat Badan Lahir Normal (BBLN) (Hapisah, Dasuki, Probandari, 2010).

Menurut hasil penelitian, wanita yang memiliki riwayat kehamilan berisiko, (seperti mengalami keguguran berulang lebih dari tiga kali, kelahiran prematur, kematian pada bayi yang baru lahir) memiliki kualitas hidup yang buruk dibandingkan dengan yang tidak memiliki riwayat kehamilan berisiko. Selain kualitas hidup yang buruk, wanita yang memiliki riwayat berisiko menunjukkan gejala kecemasan, depresi dalam kehamilan berikutnya (Cauto, et al, 2009).

Endang Fourianalistyawati, (2016) dalam penelitiannya menyebutkan bahwa terdapat 55 subjek dengan kriteria hamil risiko tinggi di Jakarta, yang memiliki nilai tingkat depresi yang rendah sebanyak 21,8\%, kategori sedang sebanyak $63,6 \%$ dan kategori tinggi sebanyak 14,5\%. Hal ini menunjukkan bahwa ibu hamil risiko tinggi yang memiliki tingkat depresi rendah lebih besar jumlahnya dari pada ibu hamil risti yang memiliki tingkat yang tinggi.

\section{Hubungan antara Pengetahuan tentang Kehamilan Resiko Tinggi dan Tingkat Depresi pada Ibu Hamil}

Berdasarkan hasil penelitian yang telah dilakukan peneliti terkait tingkat pengetahuan tentang kehamilan resiko tinggi dan tingkat depresi pada ibu hamil, dapat dilihat bahwa dari hasil kuesioner yang telah diisi oleh responden, tercatat sekitar 18 orang memiliki tingkat pengetahuan yang rendah dan 17 orang memiliki tingkat pengetahuan yang tinggi. Perbedaan keduanya hanya selisih 1 . Kemudian, jika dilihat dari tingkat depresi, tercatat sekitar 25 orang memiliki tingkat depresi yang ringan dan 10 orang mengalami depresi yang berat. Berdasarkan hasil uji korelasi spearman, antara variabel pengetahuan tentang kehamilan resiko tinggi dan variabel depresi dalam kehamilan diperoleh koefisien korelasi sebesar $-0,488$ dengan nilai signifikansi sebesar 0,003. Hasil tersebut menunjukkan adanya korelasi negatif signifikan, artinya semakin tinggi pengetahuan yang dimiliki ibu hamil akan 
berpengaruh terhadap semakin rendah tingkat depresi kehamilannya. Koefisien korelasi sebesar -0,488 juga menunjukkan tingkat hubungan antara variabel pengetahuan tentang kehamilan resiko tinggi dan variabel depresi dalam kehamilan berada pada tingkat sedang.

\section{Kesimpulan}

Berdasarkan penelitian "Hubungan antara Pengetahuan tentang Kehamilan Resiko Tinggi dan Tingkat Depresi pada Ibu Hamil” di wilayah RT.05 Kelurahan Karang Ambun, Kecamatan Tanjung Redeb, Kabupaten Berau menunjukkan hasil bahwa pengetahuan ibu hamil tentang kehamilan resiko tinggi dengan kategori rendah sebesar $51,4 \%$ (18 orang), sedangkan tingkat pengetahuan ibu hamil dengan kategori tinggi sebesar $48,6 \%$ (16 orang).

Tingkat depresi, didapatkan hasil bahwa ibu hamil yang memiliki tingkat depresi ringan sebesar $71,4 \%$ (25 orang), dan untuk depresi berat sebesar 28,6\% (10 orang). Dan berdasarkan didapatkan kesimpulan bahwa kedua variabel memiliki hubungan yang korelasi negatif signifikan yang artinya semakin tinggi pengetahuan yang dimiliki ibu hamil akan berpengaruh terhadap semakin rendah tingkat depresi kehamilannya.

\section{Referensi}

Aji, A. K. (2017). Sikap Dengan Perilaku
Masyarakat Tentang Pertolongan Pertama Korban Kecelakaan Lalu Lintas. Sekolah Tinggi Ilmu Kesehatan Insan Cendekia Medika

Baiturrahim, J. A . (2019). Karakteristik ibu yang mengalami depresi dalam kehamilan. 8(1), 99-106.

Cella Marcelya, E. S. (2018). Faktor pengaruh risiko kehamilan " $4 \mathrm{t}$ " pada ibu hamil. 1(September), 120-127.

Cashion, Perry, Lowdermilk. (2013). Keperawatan Maternitas Edisi 8. Singapore: Elsevier Morby.

De Lima, T. H. B., Katz, L., Kassar, S. B., \& Amorim, M. M. (2018). Neonatal near miss determinants at a maternity hospital for high-risk pregnancy in Northeastern Brazil: a prospective study. BMC Pregnancy and Childbirth, 18(1), 1-8. https://doi.org/10.1186/s12884-0182020-X

Fauzy, R., \& Fourianalistyawati, E. (2017). Hubungan antara Depresi dengan Kualitas Hidup pada Ibu Hamil Berisiko Tinggi. Journal Psikogenesis, 4(2), 206. https://doi.org/10.24854/jps.v4i2.350

Hanum. (2018). Hubungan Pengetahuan dan Sikap Ibu Hamil dengan Kejadian Resiko Tinggi Kehamilan di Klinik Pratama Singgal Medan. Jurnal Maternitas Kebidanan (1.3(2), 269-270.

Hutahaean, Serri. 2013.Perawatan Antenatal. 
Jakarta: Salemba Medika

Indriyani, D. (2013).Aplikasikonsep dan teori keperawatan maternitas postpartum dengan kematian janin.Jogjakarta : ArRuzz Media

Lambogia.

https://www.academia.edu/36593050/Bu

ku_Ajar_Keperawatan_Maternitas_Kons

ep_Teori_dan_Modul_Praktikum

Masturoh, I., \& Anggita T., N. (2018).

Metodologi Penelitian Kesehatan. Jakarta:

Kementerian Kesehatan Republik

Indonesia.

Mamuroh, L., Sukmawati, S., \& Widiasih, R. (2019). Pengetahuan Ibu Hamil tentang Gizi Selama Kehamilan pada Salah Satu Desa di Kabupaten Garut. Jurnal Ilmiah Keperawatan Sai Betik, 15(1), 66. https://doi.org/10.26630/jkep.v15i1.1544

Mandiri, J. S., \& Khadijah, S. (2018). Kata Kunci: Kehamilan, Resiko Tinggi, Pengetahuan, Buku KIA Penerbit: Poltekkes Kemenkes Padang , http://jurnal.poltekkespadang.ac.id/ojs/ind ex.php/jsm Penerbit : Poltekkes Kemenkes Padang http://jurnal.poltekkespadang.ac.id/ojs/ind ex.php/jsm. 13(1), 27-34.

Notoatmodjo, S. (2007). Promosi Kesehatan dan Ilmu Perilaku. Jakarta: Rineka Cipta. $1-260$.

Nursalam. (2011). Konsep dan Penerapan
Metodologi Penelitian Ilmu

Keperawatan. Jakarta: Salemba Medika. Nursalam. (2015). Metodologi Penelitian Ilmu Keperawatan: Pendekatan Praktis. Jakarta: Salemba Medika.

Rachmi, A. S. (2012). Aspirin Dosis Rendah Efektif Menurunkan Resistensi Arteri Uterina yang Abnormal pada Ibu Hamil Usia Kehamilan 16 - 24 Minggu Low Dose Aspirin is Effective in Reducing Abnormal Uterine Artery Resistance in Pregnant Women with Gestational Age 16-24 Weeks.

Rahmadita, S. S. (2018). Pengaruh Pendidikan Kesehatan Dengan Infografis Melalui Media Sosial Terhadap Perilaku Pertolongan Pertama Pada Kecelakaan Di Pengemudi Ojek Online Surabaya, 125.

Rsud, D. I., \& Achmad, A. (2019). AlInsyirah Midwifery Jurnal Ilmu Kebidanan ( Journal of Midwifery Sciences ). 8, 1-5.

Swarjana, I. K. (2012). Metodologi Penelitian Kesehatan. Yogyakarta: ANDI.

Yeoh, P. L., Hornetz, K., \& Dahlui, M. (2016). Antenatal care utilisation and content between low-risk and high-risk pregnant women. PLoS ONE, 11(3), 117.https://doi.org/10.1371/journal.pone .01521679 